Supporting Information

\title{
Aliphatic Group-Tethered Iridium Complex as a Theranostic Agent against Malignant Melanoma Metastasis
}

Ke-Jia Wu,${ }^{+}$Shih-Hsin Ho, ${ }^{{ }^{\perp}}$ Jia-Yi Dong, ${ }^{\#}$ Ling Fu, ${ }^{\llbracket l}$ Shuang-Peng Wang, ${ }^{\#}$ Hao Liu, ${ }^{\S}$ Chun Wu,,${ }^{\S}$ Chung-Hang Leung, ${ }^{* \dagger}$ Hui-Min David Wang $* \Phi, \lambda, \$$ and Dik-Lung Ma*\$

${ }^{\dagger}$ State Key Laboratory of Quality Research in Chinese Medicine, Institute of Chinese Medical Sciences, University of Macau, Taipa 999078, Macao SAR, China.

* State Key Laboratory of Urban Water Resource and Environment, School of Environment, Harbin Institute of Technology, Harbin, 150090, P. R. China.

\# Joint Key Laboratory of the Ministry of Education, Institute of Applied Physics and Materials Engineering, University of Macau, Taipa 999078, Macao SAR, China.

"I Graduate Institute of Biomedical Engineering, National Chung Hsing University, Taichung 402, Taiwan.

${ }^{\lambda}$ Graduate Institute of Medicine, College of Medicine, Kaohsiung Medical University, Kaohsiung 807, Taiwan.

\$ Department of Medical Laboratory Science and Biotechnology, China Medical University, Taichung City 404, Taiwan.

$\S$ Department of Chemistry, Hong Kong Baptist University, Kowloon Tong, Hong Kong 999077, P. R China.

${ }^{\perp}$ These authors contributed equally to this work

\section{Corresponding Author}

E-mail, duncanleung@um.edu.mo

E-mail,davidw@dragon.nchu.edu.tw

E-mail,edmondma@hkbu.edu.hk 


\section{Methods}

General experimental. Mass spectrometry was performed at the Mass Spectroscopy Unit at the Department of Chemistry, Hong Kong Baptist University, Hong Kong (China). Deuterated solvents for NMR purposes were obtained from Armar and used as received. ${ }^{1} \mathrm{H}$ and ${ }^{13} \mathrm{C}$ NMR were recorded on a Bruker Advance 400 spectrometer operating at $400 \mathrm{MHz}\left({ }^{1} \mathrm{H}\right)$ and $100 \mathrm{MHz}\left({ }^{13} \mathrm{C}\right) .{ }^{1} \mathrm{H}$ and ${ }^{13} \mathrm{C} \mathrm{chemical}$ shifts were referenced internally to solvent shift (Acetonitrile- $d_{3}:{ }^{1} \mathrm{H}, \delta 1.94,{ }^{13} \mathrm{C} \delta 118.7$; Acetone- $d_{6}:{ }^{1} \mathrm{H} \delta 2.05,{ }^{13} \mathrm{C} \delta 29.7$ ). Chemical shifts (d) are quoted in ppm, the downfield direction being defined as positive. Uncertainties in chemical shifts are typically $\pm 0.01 \mathrm{ppm}$ for ${ }^{1} \mathrm{H}$ and \pm 0.05 for ${ }^{13} \mathrm{C}$. Coupling constants are typically $\pm 0.1 \mathrm{~Hz}$ for ${ }^{1} \mathrm{H}-{ }^{1} \mathrm{H}$ and $\pm 0.5 \mathrm{~Hz}$ for ${ }^{1} \mathrm{H}-{ }^{13} \mathrm{C}$ couplings. The following abbreviations are used for convenience in reporting the multiplicity of NMR resonances: $s$, singlet; $d$, doublet; $t$, triplet; q, quartet; m, multiplet. All NMR data was acquired and processed using standard Bruker software (Topspin).

Chemicals and reagents: Dual-Luciferase ${ }^{\circledR}$ Reporter Assay System was purchased from (Promega, Madison, WI, USA). p53Luciferase plasmid was purchased from Beyotime (Beyotime, Shanghai, China). Iridium chloride hydrate ( $\left.\mathrm{IrCl}_{3} \cdot \mathrm{xH}_{2} \mathrm{O}\right)$ and rhodium chloride hydrate $\left(\mathrm{RhCl}_{3} \times \mathrm{H}_{2} \mathrm{O}\right)$ were purchased from Precious Metals Online (Australia). The synthesis and stability experiments of compounds were described in SI Materials and Methods. Transfection Reagent was obtained from Thermo Scientific (Thermo Scientific, St Leon-Rot, Germany). p53 antibody, S100B antibody were purchased from Abcam (Abcam Inc., Cambridge, MA, USA), MMP-2 antibody, p21 antibody, Bax antibody, and GAPDH antibody were purchased from CST (CST Inc., Massachusetts, USA). S100B protein was purchased from R\&D Systems (R\&D Systems Inc., Minneapolis, Minnesota, USA). p53 peptide was purchased from GL Biochem Ltd. (GL Biochem Ltd., Shanghai, China). All the compounds were dissolved in dimethyl sulfoxide (DMSO). The final concentration of DMSO is less than $0.1 \%$. Human malignant melanoma (A375 cells) was obtained from American Type Culture Collection. The hepatocyte cells (LO2 cells) was obtained from Chinese Academy of Science (Cell Biology of Shanghai Institute, Shanghai, China).

\section{Synthesis of rhodium(III) and Iridium(III) complexes}

Preparation of the precursor complexes $\left[\mathrm{M}_{2}\left(\mathbf{C}^{\wedge} N\right)_{4} \mathrm{Cl}_{2}\right]$. A solution of rhodium(III)/iridium(III) chloride (1 eq.) and corresponding $\mathrm{C}^{\wedge} \mathrm{N}$ ligands (2.1 eq.) in a mixture of methoxyethanol:water $(3: 1,48 \mathrm{~mL})$ was heated under reflux overnight under a nitrogen atmosphere. The reaction mixture was cooled to room temperature. The solid was collected by filtration, washed with additional portions of water $(2$ $\times 100 \mathrm{~mL})$ and diethyl ether $(2 \times 50 \mathrm{~mL})$ and dried to yield the corresponding precursor complexes.

Preparation of the final complexes. A suspension of cyclometallated dimer complex $\left[\mathrm{Rh}_{2}\left(\mathrm{C}^{\wedge} \mathrm{N}\right)_{4} \mathrm{Cl}_{2}\right]$ or $\left[\mathrm{Ir}_{2}\left(\mathrm{C}^{\wedge} \mathrm{N}\right)_{4} \mathrm{Cl} \mathrm{l}_{2}\right](1$ eq. $)$ and the corresponding $\mathrm{N}^{\wedge} \mathrm{N}$ ligands (2.1 eq.) in a mixture of methanol:dichloromethane (1:1,20 mL) was refluxed overnight under a nitrogen atmosphere. The resulting solution was then allowed to cool to room temperature, and filtered to remove unreacted cyclometallated dimer. To the filtrate, an aqueous solution of ammonium hexafluorophosphate (excess) was added and the filtrate was reduced in volume by rotary evaporation until precipitation of the crude product occurred. The precipitate was then filtered and washed with several portions of water $(2 \times 50 \mathrm{~mL})$ followed by diethyl ether $(2 \times 50 \mathrm{~mL})$. The product was recrystallized by acetonitrile:diethyl e ther vapor diffusion to yield the titled compounds.

Complex 1: (Yield: 52\%) ${ }^{1} \mathrm{H}$ NMR $(400 \mathrm{MHz}$, Acetone-d6) $\delta 8.50(\mathrm{~s}, 4 \mathrm{H}), 8.43$ (d, J = 2.0 Hz, 2H), 8.24 (d, J = 8.0 Hz, 2H), 8.21 (d, J $=6.0 \mathrm{~Hz}, 2 \mathrm{H}), 7.93(\mathrm{~d}, \mathrm{~J}=8.0 \mathrm{~Hz}, 2 \mathrm{H}), 7.70(\mathrm{~d}, \mathrm{~J}=8.0 \mathrm{~Hz}, 2 \mathrm{H}), 7.47-7.43(\mathrm{~m}, 2 \mathrm{H}), 7.37(\mathrm{~d}, \mathrm{~J}=8.8 \mathrm{~Hz}, 2 \mathrm{H}), 7.18-7.14(\mathrm{~m}, 2 \mathrm{H}), 7.11-$ $7.08(\mathrm{~m}, 2 \mathrm{H}), 6.84-6.80(\mathrm{~m}, 2 \mathrm{H}), 6.57(\mathrm{~d}, \mathrm{~J}=7.6 \mathrm{~Hz}, 2 \mathrm{H}), 1.29(\mathrm{~s}, 18 \mathrm{H}) .{ }^{13} \mathrm{C}$ NMR $(101 \mathrm{MHz}$, Acetone-d6) $\delta 171.4,165.2,156.6$, 152.6, 148.7, 148.5, 147.0, 141.1 135.3, 131.7, 131.4, 130.2, 128.9, 128.3, 127.6, 126.1, 125.7, 123.7, 122.0, 118.9, 36.3, 29.9. MALDI-TOF-HRMS: calcd. for $\mathrm{C}_{48} \mathrm{H}_{44} \mathrm{IrN}_{4}\left[\mathrm{M}-\mathrm{PF}_{6}\right]^{+}: 869.3195$ Found: 869.3153 Anal.: $\left(\mathrm{C}_{48} \mathrm{H}_{44} \mathrm{IrN}_{4} \mathrm{PF} \mathrm{F}_{6}\right) \mathrm{C}, \mathrm{H}, \mathrm{N}$ : calcd. 56.85, 4.37, 5.52 ; found $56.63,4.41,5.62$ (Figure $\mathrm{S} 1$ ).

Complex 2: Reported. ${ }^{1}$

Complex 3: Reported. ${ }^{2}$

Complex 4: (Yield: 59\%) ${ }^{1} \mathrm{H}$ NMR (400 MHz, Acetone- $\left.\mathrm{d}_{6}\right) \delta 8.80(\mathrm{~d}, \mathrm{~J}=2.0 \mathrm{~Hz}, 2 \mathrm{H}), 8.59-8.49(\mathrm{~m}, 4 \mathrm{H}), 8.28-8.19(\mathrm{~m}, 4 \mathrm{H}), 8.00-7.92$ $(\mathrm{m}, 4 \mathrm{H}), 7.48(\mathrm{t}, \mathrm{J}=8.0 \mathrm{~Hz}, 2 \mathrm{H}), 7.41(\mathrm{~d}, \mathrm{~J}=8.3 \mathrm{~Hz}, 2 \mathrm{H}), 7.20(\mathrm{~m}, 4 \mathrm{H}), 6.84(\mathrm{t}, \mathrm{J}=6.4 \mathrm{~Hz}, 2 \mathrm{H}), 6.55(\mathrm{~d}, \mathrm{~J}=8.0 \mathrm{~Hz}, 2 \mathrm{H}) .{ }^{13} \mathrm{C} \mathrm{NMR}(101$ $\mathrm{MHz}$, Acetone- $\left.\mathrm{d}_{6}\right) \delta 170.97,156.51,150.87,149.70,148.16,146.70,141.41,136.71,135.23,132.90,132.16,131.57,130.31,128.95$ 128.86, 128.37, 127.77, 125.55, 124.00, 118.95. MALDI-TOF-HRMS: calcd. for $\left.\mathrm{C}_{38} \mathrm{H}_{32} \mathrm{IrN}_{4}[\mathrm{M}-\mathrm{PF}]_{6}\right]^{+}$: 915.0123 Found: 915.0135 . Anal. $\left(\mathrm{C}_{40} \mathrm{H}_{26} \mathrm{Br}_{2} \mathrm{~F}_{6} \mathrm{IrN} \mathrm{N}_{4} \mathrm{P}\right) \mathrm{C}, \mathrm{H}, \mathrm{N}$ : calcd. 45.34, 2.82, 5.29; found 45.43, 2.82, 5.01 (Figure S2).

\section{Complex 5: Reported. ${ }^{1}$}

Complex 6: Reported. ${ }^{3}$

Complex 7: Reported. ${ }^{4}$

Complex 8: (Yield: 62.3\%) ${ }^{1} \mathrm{H}$ NMR $\left(400 \mathrm{MHz}\right.$, Acetone- $\left.\mathrm{d}_{6}\right) \delta 8.89(\mathrm{~d}, \mathrm{~J}=0.8 \mathrm{~Hz}, 2 \mathrm{H}), 8.72(\mathrm{~d}, \mathrm{~J}=3.2 \mathrm{~Hz}, 2 \mathrm{H}), 8.18(\mathrm{~d}, \mathrm{~J}=5.6 \mathrm{~Hz}$, $2 \mathrm{H}$ ), $7.74(\mathrm{dd}, \mathrm{J}=6.0,2.0 \mathrm{~Hz}, 2 \mathrm{H}), 7.66(\mathrm{dd}, \mathrm{J}=8.0,0.8 \mathrm{~Hz}, 2 \mathrm{H}), 7.18(\mathrm{~d}, \mathrm{~J}=2.0 \mathrm{~Hz}, 2 \mathrm{H}), 7.10-7.06(\mathrm{~m}, 2 \mathrm{H}), 6.91-6.87(\mathrm{~m}, 2 \mathrm{H}), 6.72-$ $6.70(\mathrm{~m}, 2 \mathrm{H}), 6.36(\mathrm{dd}, \mathrm{J}=7.2,1.2 \mathrm{~Hz}, 2 \mathrm{H}), 1.46(\mathrm{~s}, 18 \mathrm{H}) ;{ }^{13} \mathrm{C}$ NMR $\left(100 \mathrm{MHz}\right.$, Acetone- $\left.\mathrm{d}_{6}\right) \delta 165.1,157.4,151.5,144.3,139.3$, 
134.0, 133.7, 128.8, 127.4, 126.0, 124.0, 122.6, 112.8, 109.2, 36.4, 30.5; MALDI-TOF-HRMS: Calcd. for $\mathrm{C}_{36} \mathrm{H}_{38} \mid \mathrm{IN}_{6}\left[\mathrm{M}-\mathrm{PF}_{6}\right]^{+}$: 747.2787, found: 747.2714; Anal. $\left(\mathrm{C}_{36} \mathrm{H}_{38} \mathrm{IrN}_{6} \mathrm{PF}_{6}\right) \mathrm{C}, \mathrm{H}, \mathrm{N}$ : calcd. 48.48, 4.29, 9.42, found 48.42, 4.19, 9.30 (Figure S3).

Complex 9: Reported. ${ }^{5}$

Complex 10: Reported. ${ }^{6}$

Complex 11: Reported. ${ }^{7}$

Complex 12: Reported. ${ }^{1}$

Complex 13: Reported. ${ }^{8}$

Complex 14: (Yield: 61\%) ${ }^{1} \mathrm{H}$ NMR (400 MHz, Acetone-d6) $\delta 9.08(\mathrm{dd}, \mathrm{J}=6.5,3.0 \mathrm{~Hz}, 2 \mathrm{H}), 8.91$ (d, J = 1.6 Hz, 2H), 8.46 (d, J = 7.9 $\mathrm{Hz}, 2 \mathrm{H}), 8.10-8.05(\mathrm{~m}, 2 \mathrm{H}), 7.98-7.89(\mathrm{~m}, 4 \mathrm{H}), 7.83(\mathrm{~d}, \mathrm{~J}=5.7 \mathrm{~Hz}, 2 \mathrm{H}), 7.72-7.59(\mathrm{~m}, 6 \mathrm{H}), 7.21(\mathrm{td}, \mathrm{J}=7.2 \mathrm{~Hz}, 1.2 \mathrm{~Hz}, 2 \mathrm{H}), 6.98$

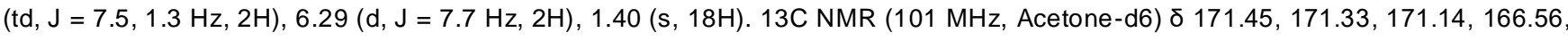
$165.81,165.64,164.31,159.36,154.67,154.57,149.69,149.65,145.61,142.56,140.44,140.38,137.23,137.20,132.79,132.49$, $131.91,131.80,130.30,130.10,129.57,129.36,128.46,127.96,127.11,126.56,126.50,126.27,125.50,124.90,124.86,123.20$, 122.03, 121.77, 121.70, 121.40, 35.50. MALDI-TOF-HRMS: calcd. for $\mathrm{C}_{48} \mathrm{H}_{44} \mathrm{RhN}_{4}\left[\mathrm{M}-\mathrm{PF}_{6}\right]^{+}:$779.2616 Found: 779.2645 . Anal.: $\left(\mathrm{C}_{48} \mathrm{H}_{44} \mathrm{~F}_{6} \mathrm{RhN}_{4} \mathrm{P}+0.5 \mathrm{H}_{2} \mathrm{O}\right) \mathrm{C}, \mathrm{H}, \mathrm{N}$ : calcd. 61.74, 4.86, 6.00; found 61.73, 4.90, 5.99 (Figure S4).

UV/Vis absorbance spectroscopy: Complex $7(5 \mu \mathrm{M})$ was added to $0,0.01,0.1,1,10 \mathrm{mM}$ of $\mathrm{Ca}^{2+}$ in $20 \mathrm{mM}$ Tris- $\mathrm{HCl}$ buffer $(\mathrm{pH}=$ 7.4) at $25^{\circ} \mathrm{C}$. Absorption spectra were recorded on Cary UV-100 Spectrophotometer at a range of $200 \mathrm{~nm}$ to $800 \mathrm{~nm}$. The absorbance was corrected by subtraction of $20 \mathrm{mM}$ Tris-HCl buffer $(\mathrm{pH}=7.4)$ as the background absorbance.

Stability experiments. For ${ }^{1} \mathrm{H}$ NMR, complex 7 (5 mM) was dissolved in $90 \%\left[d_{6}\right] \mathrm{DMSO} / 10 \% \mathrm{D}_{2} \mathrm{O}$ at $25{ }^{\circ} \mathrm{C}$ over 7 days. ${ }^{1} \mathrm{H}$ NMR measurements were carried out on a $400 \mathrm{MHz}$ Bruker instrument. For UV-Visible spectrometry, complex 7 (5 $\mu \mathrm{M})$ was dissolved in $80 \%$ acetonitrile/20\% $20 \mathrm{mM}$ Tris- $\mathrm{HCl}$ buffer $(\mathrm{pH}=7.4)$ at $25^{\circ} \mathrm{C}$ over 7 days. Absorption spectra were recorded on a Cary UV-100 Spectrophotometer at a range of $200 \mathrm{~nm}$ to $800 \mathrm{~nm}$. The absorbance of complex 7 was corrected by subtraction of $80 \%$ acetonitrile/20\% $20 \mathrm{mM}$ Tris- $\mathrm{HCl}$ buffer $(\mathrm{pH}=7.4)$ as the background absorbance.

Cyclic voltammetry (CV). Cyclic voltammetry measurements of complexes $\mathbf{7}$ and $\mathbf{1 4}$ were carried out on a CHI 650E electrochemical workstation (Chenhua, Shanghai, China) with a conventional three-electrode system consisting of a modified working electrode, a platinum wire counter electrode and an $\mathrm{Ag} / \mathrm{AgCl}$ reference electrode. Meantime, the electrochemical characteristics of the rhodium/ iridium complexes were investigated in Tris-buffer by using $\mathrm{CV}$ experiments from $-1.5 \mathrm{~V}$ to $1.5 \mathrm{~V}$.

Cell cultures: The cells were cultivated in DMEM medium with $1 \%$ penicillin (100 units $/ \mathrm{mL}) /$ streptomycin $(100 \mu \mathrm{g} / \mathrm{mL})$ and $10 \%$ fetal bovine serum (FBS). Cells were maintained at a density of $6 \times 10^{5} \mathrm{cell} / \mathrm{mL}$ in $5 \% \mathrm{CO}_{2}$ at $37^{\circ} \mathrm{C}$.

Flow cytometry protein interaction assay. The EZ-Link Sulfo-NHS-LC-Biotinylation Kit was used to conjugate biotin and S100B protein to polystyrene beads in $\mathrm{Ca}^{2+}$ buffer. The procedure was performed as described. ${ }^{9}$ After conjugating $\mathrm{S} 100 \mathrm{~B}$ protein to the beads, human p53 peptide labeled with FITC was added, and FITC fluorescence was detected by flow cytometry.

Co-IP assay: The co-IP assay was performed as previously described. ${ }^{10-11}$ Briefly, A375 cells were seeded at a density of $2 \times 10^{6}$ cells in a six-well plate. Cells were treated with the 0.1 and $1.0 \mu \mathrm{M}$ complex 7 or $10 \mu \mathrm{M} \mathrm{SBi1}$ for $12 \mathrm{~h}$. Cells were lysed and protein samples were collected. The concentration of protein samples was calculated using the Pierce BCA protein assay kit. $30 \mu \mathrm{g}$ of each protein sample were incubated overnight with $10 \mu \mathrm{L}$ pre-incubated anti-p53 magnetic beads according to the manufacturer's protocol. The complex was washed 5 times to elute non-specific and non-cross-linked antibodies. Then, the precipitated proteins were subjected to SDS-PAGE and analyzed by Western blotting with the indicated antibodies.

Western blotting: A375 cells were seeded at a density of $6 \times 10^{5} \mathrm{cell}$ in a 6-well plate overnight. Cells were treated with complex 7 (in $0.1 \%$ DMSO), SBi1, or vehicle control in $1 \%$ FBS medium for an additional $12 \mathrm{~h}$. Cells were lysed, and protein samples were collected. Western blotting analysis was performed as described. ${ }^{12}$

Transient transfection: A375 cells were seeded in a culture dish overnight before transfection. p53-luciferase plasmid, and TurboFect reagent were mixed together in Dulbecco's modified eagle medium (DMEM) without FBS and the resulting solution was incubated for $20 \mathrm{~min}$ at $37^{\circ} \mathrm{C}$. The mixture was then added to the $\mathrm{A} 375$ cells in the wells. The cells were incubated for $12 \mathrm{~h}$ at $37^{\circ} \mathrm{C}$ in a $\mathrm{CO}_{2}$ incubator before use.

Luciferase reporter assay: The inhibition of p53 activity was assayed by a luciferase reporter assay system (Promega, Madison, WI, USA). Briefly, A375 cells were seed at a density of $6 \times 10^{5}$ cell in a culture dish overnight. The cells were co-transfected with p53luciferase plasmid in serum-free DMEM medium using TurboFect Transfection Reagent. Then, the transfected cells were seeded in a 24-well plate and treated with an indicated concentration of 7 in $1 \%$ FBS medium for 6 h. The transfected cells were lysed by the addition of $160 \mu \mathrm{L}$ Passive Lysis Buffer (PLB). $50 \mu \mathrm{L}$ of the cell lysates were transferred to a 96-well white plate followed by adding $50 \mu \mathrm{L}$ of 
luciferase reporter reagent (LAR). The transcriptional activity was determined by measuring the activity of firefly luciferase in SpectraMax M5 microplate reader (Molecular Devices).

In ductively coupled plasma mass spectrometry (ICP-MS): $500 \mu \mathrm{L}$ of the cell samples from mitochondria isolation, nuclear extraction or whole cell lysate was then combined with $1500 \mu \mathrm{L}$ of a $68 \% \mathrm{HNO}_{3}: \mathrm{H}_{2} \mathrm{O}_{2}(\mathrm{v} / \mathrm{v}=4: 1)$ solution, while the remainder of the lysate was quantified for protein by a bicinchoninic assay (BCA). The $2 \% \mathrm{HNO}_{3}$ solution was analyzed for iridium uptake levels on a Thermo iCAP Qs ICP-MS. Iridium uptake levels in each sample were normalized to the concentration of corresponding protein and calculated each value of $\mathrm{ng}$ [lridium]/mg [protein].

Knockdown assay: $A 375$ cells were seeded in 6-well plate at 80\% confluences in DMEM medium for 24 h. Lipo3000 reagent and S100B siRNA (5' - GAA CAU GAG UGA GAU UAG ATT - 3' (sense), 5' - UCU AAU CUC ACU CAU GUU CTT - 3' (antisense)) was gently mixed and incubated for $20 \mathrm{~min}$ at room temperature. Then, $500 \mu \mathrm{L}$ of the Lipo3000/siRNA mixture were added to each well. Cells were incubated at $37^{\circ} \mathrm{C}$ in a $\mathrm{CO}_{2}$ incubator for $48 \mathrm{~h}$ post-transfection before further research.

Cellular thermal shift assay: Cellular thermal shift assay was performed to monitor the target engagement of 7 in A375 cell lysates. Briefly, cell lysates from $2 \times 10^{6} \mathrm{~A} 375$ cells were collected, diluted in PBS and separated in the same aliquots. Each aliquot was treated with $7(10.0 \mu \mathrm{M})$ or DMSO $30 \mathrm{~min}$ after incubation at room temperature, the compound-treated lysates were divided into $50 \mu \mathrm{L}$ in each of PCR tubes and heated individually at different temperatures (Veriti thermal cycler, Applied Biosystems/Life Technologies). The heated lysates were centrifuged and the supernatants were analyzed by SDS-PAGE followed by immunoblotting analysis by probing with the indicated antibody.

Protein thermal shift assay: To evaluate binding affinity of complex 7 with S100B protein, the GloMelt ${ }^{\text {TM }}$ Thermal Shift Protein Stability Kit was used. Briefly, after incubating S100B protein with complex 7 for $30 \mathrm{~min}$, GloMelt dye was added. Reactions were performed in triplicate and fluorescence signals were recorded in am Applied Biosystems ${ }^{\mathrm{TM}} \mathrm{ViiA}^{\mathrm{TM}} 7$ system. The data were exported to Excel and the fluorescence signal of each samples was plotted. A significant increase in slope corresponds to the melting temperature of the protein.

Chromatin immunoprecipitation (ChIP) assay: A375 cells were treated with 7, SBi1 or vehicle for $12 \mathrm{~h}$. The cells were cross-linked by incubating with $1 \%(\mathrm{v} / \mathrm{v})$ formaldehyde-containing medium for 10 minutes at $37^{\circ} \mathrm{C}$. S100B antibody was used to precipitate proteinDNA complexes. The protein-DNA complexes were collected with Protein A Sepharose beads (Millipore), eluted, and reverse crosslinked. Complexes were purified with ChIP DNA Purification Kit (Active Motif, No. 58002). Recovered DNAs were analyzed by real-time qPCR (ViiA ${ }^{\text {TM }} 7$ System, ABI). The PCR primers for the target promoters are listed in Supplementary Table S1. ChIP-PCR analysis was performed following a published protocol. ${ }^{13}$

Immun ofluorescence: After washing with phosphate-buffered saline (PBS) three times, the cells were treated with $4 \%$ PFA for 30 min followed by washing with PBS three times. Then, cells were incubated with $0.5 \%$ Triton $\mathrm{X}-100$ for 30 min at room temperature, then washed with PBS three times. After blocking with $5 \%$ BSA for $30 \mathrm{~min}$, cells were incubated with $\mathrm{S} 100 \mathrm{~B}$ antibody overnight at $4{ }^{\circ} \mathrm{C}$ (primary antibody) and then with secondary antibody for $3 \mathrm{~h}$ at room temperature.

Cell imaging: A375 cells were seeded into a glass-bottomed dish ( $35 \mathrm{~mm}$ dish with $20 \mathrm{~mm}$ wells) for $24 \mathrm{~h}$. Cells were then incubated with complex 7 for the indicated time periods and concentrations and then washed with phosphate-buffered saline three times. Luminescence imaging was performed on a Leica TCS SP8 confocal laser scanning microscope system. The excitation wavelength was 500-700 nm.

Quantitative reverse transcription polymerase chain reaction (qRT-PCR): To an eppendorf was added $1 \mu \mathrm{L}$ of RNA, $4 \times$ gDNA Wisper Mix $4 \mu \mathrm{L}$, Oligo-(dT)23 VN $(50 \mu \mathrm{M}) 1 \mu \mathrm{L}$, random hexamers (50 ng/uL) $1 \mu \mathrm{l}$, and RNAse-free $\mathrm{ddH}_{2} \mathrm{O}$ added to $16 \mu \mathrm{L}$. The mixture was incubated at $42{ }^{\circ} \mathrm{C}$ for $2 \mathrm{~min}$. Then, $2 \mu \mathrm{L}$ of $10 \times \mathrm{RT}$ Mix and $2 \mu \mathrm{l}$ of Hiscript Il enzyme Mix were added, and then the mixture was sequentially heated at $25^{\circ} \mathrm{C}$ for $5 \mathrm{~min}, 50^{\circ} \mathrm{C}$ for $15 \mathrm{~min}$, and $85^{\circ} \mathrm{C}$ for $2 \mathrm{~min}$ to configure cDNA. The cDNA was quantified using the BioTek Take Micro-Volume Plate, with $2 \mu \mathrm{L}$ of cDNA added per well. The cDNA concentration was diluted to $20 \mathrm{ng} / \mu \mathrm{L} u s i n g ~ d d H_{2} \mathrm{O}$. For qRT-PCR, a $10 \mu \mathrm{L}$ reaction contained a 3 mixture of two reverse transcriptases: $10 \mu \mathrm{L}$ of $2 \times$ AceQ qPCR SYBR Green Master Mix (Vazyme Biotech Co.,Ltd) with Hot Start Taq polymerase, $0.5 \mu \mathrm{L}$ of primers, and $0.5 \mu \mathrm{L}(20 \mathrm{ng} / \mathrm{mL})$ of template. The StepOnePlus ${ }^{\mathrm{TM}}$ System was used for all real-time PCR assays. ${ }^{14}$ The reaction was activated the AceTaq ${ }^{\circledR}$ DNA Polymerase at $95^{\circ} \mathrm{C}$ for 5 min. This was then amplified for 40 cycles at $95^{\circ} \mathrm{C}$ for $3 \mathrm{~s}$ for denaturation, annealing, and acquisition at $60^{\circ} \mathrm{C}$ for $40 \mathrm{~s}$. It was finally elongated at $95^{\circ} \mathrm{C}$ for $15 \mathrm{~s}$. Fluorescence can be measured after the annealing phase. With an Applied Biosystems ${ }^{\mathrm{TM}}$ MicroAmp $^{\mathrm{TM}}$ Fast Optical 96-Well Reaction Plate, $10 \mu \mathrm{L}$ of the reaction mix was added, as well as the 96 -SYBR-Green assays on the StepOnePlus ${ }^{\text {TM }}$ Real Time System. To prepare the assay, all of the reagents were kept either on a cooling block or on ice. The $\Delta \Delta \mathrm{Ct}$ method was used in 
calculations. For each sample three independent QPCR experiments were performed. Each experiment involved three replicates for each gene. Expression of GAPDH was used as an internal control.

Transwell assay: A375 cells were seeded at $10^{5}$ cells per well in the transwell inserts. The transwell inserts and the 24 -well plates were incubated $5 \% \mathrm{CO}_{2}$ at $37^{\circ} \mathrm{C}$ for $12 \mathrm{~h}$.

MTT assay: A375 and LO2 cells were seeded at 5000 cells per well in a 96-well plates and incubated overnight at $37{ }^{\circ} \mathrm{C}$. The cells were treated with 7 at a final concentration from 0.01 to $10 \mu \mathrm{M}$ for $72 \mathrm{~h}$. Then 3-(4,5-dimethylthiazol-2-yl)-2,5-diphenyltetrazolium bromide (MTT) reagent was added to each well at a final concentration of $0.5 \mathrm{mg} / \mathrm{mL}$ for a further $4 \mathrm{~h}$. After that, the medium was replaced with $100 \mu \mathrm{L}$ DMSO. The viability of the cells was measured by recording the absorbance of each well at $490 \mathrm{~nm}$ using a SpectraMax M5 microplate reader after shaking the plate for $10 \mathrm{~min}$ at room temperature in the dark.

Melanoma xen ograft assay: NOD.CB17-Prkdcscid / NcrCrl (NOD / SCID) female mice were purchased from BioLASCO Experimental Animal Center (Taiwan Co., Ltd)., and injected with A375 cells at 8 weeks of age. The injection site was sanitized using $70 \%$ ethyl alcohol. $1 \times 10^{6}$ A375 cells dissolved in $0.1 \mathrm{~mL}$ of PBS were subcutaneously implanted into mice by using a 27 -gauge (G) needle. The mice were observed for 7 to 10 days, until the tumor grew to an appropriate size (about $100 \mathrm{~mm}^{3}$ ). The testing drug was administrated via subcutaneous injection to mice and observe its therapeutic effect on melanoma tumors ${ }^{1}$.

Metastasis tumor assay: BALB/C mice were purchased from BioLASCO Experimental Animal Center (Taiwan Co., Ltd), and injected with B16F10 cells at 8 weeks of age. B16F10 cells were detached by trypsin, and $2 \times 10^{7}$ cells were placed in an eppendorf tube, rinsed once with serum-free medium, and centrifuged at $400 \mathrm{~g}$ for 5 minutes to remove the supernatant. $1 \mathrm{ml}$ of Diluent $\mathrm{C}$ and $4 \mu \mathrm{L}$ of PKH26 dye were added and the mixture was allowed to stand for 5-10 minutes, after which an equal volume of serum was added. $5 \times 10^{5} \mathrm{cells}$ were withdrawn and the suspension was centrifuged at $400 \mathrm{~g}$ for 10 minutes. The supernatant was removed and $150 \mu \mathrm{L}$ of PBS was added to resuspend the cells, before injection into the tail vein of the mouse. After the tumor development to be visible by the IVIS system (12 days), complex 7 was delivered via intravenous injection at $1 \mathrm{mg} / \mathrm{kg}$ twice a week to mice until 36 day. The degree of metastasis of B16F10 was observed by 2D optical tomography using the Caliper IVIS Spectrum System one week later. The mice were anesthetized with the XGI-8 Anesthesia system and then placed in the IVIS machine with the internal wafer cooled to $-90{ }^{\circ} \mathrm{C}$ for fluorescence imaging.

Sample preparation from animal tissues: Mouse tumor tissues were chopped and rinsed in ice-cold saline solution. The tissue was immersed with 10 times the volume of RIPA, and then homogenized with a Mixer Mill MM 300 homogenizer (Qiagen, Chatsworth, CA) The mixture was further incubated with RIPA for $10 \mathrm{~min}$ on ice and then centrifuged at $12000 \mathrm{~g}$ for $30 \mathrm{~min}$, and the supernatant was collected and analyzed by Western blotting.

Statistical analysis: For statistical analysis, all data were analyzed with one-way analysis of variance (ANOVA) followed by the Dunnett's method for multiple comparisons by using GraphPad Prism 5.0.

\section{References}

(1) Liu, L.-J.; Wang, W.; Huang, S.-Y.; Hong, Y.; Li, G.; Lin, S.; Tian, J.; Cai, Z.; Wang, H.-M. D.; Ma, D.-L. Inhibition of the Ras/Raf interaction and repression of renal cancer xenografts in vivo by an enantiomeric iridium (III) metal-based compound. Chem. Sci. 2017, 8 (7), $4756-4763$.

(2) Wang, M.; He, B.; Lu, L.; Leung, C.-H.; Mergny, J.-L.; Ma, D.-L. Label-free luminescent detection of LMP1 gene deletion using an intermolecular G-quadruplex-based switch-on probe. Biosens. Bioelectron. 2015, 70, 338-344.

(3) Lu, L.; Zhong, H.-J.; Wang, M.; Ho, S.-L.; Li, H.-W.; Leung, C.-H.; Ma, D.-L. Inhibition of beta-amyloid fibrillation by luminescent iridium (III) complex probes. Sci. Rep 2015, 5, 14619.

(4) Lin, S.; Yang, C.; Mao, Z.; He, B.; Wang, Y.-T.; Leung, C.-H.; Ma, D.-L. A G-pentaplex-based assay for Cs+ ions in aqueous solution using a luminescent Ir (III) complex. Biosens. Bioelectron. 2016, 77, 609-612.

(5) Liu, L.-J.; He, B.; Miles, J. A.; Wang, W.; Mao, Z.; Che, W. I.; Lu, J.-J.; Chen, X.-P.; Wilson, A. J.; Ma, D.-L. Inhibition of the p53/hDM2 protein-protein interaction by cyclometallated iridium (III) compounds. Oncotarget 2016, 7 (12), 13965.

(6) Liu, L.-J.; Lu, L.; Zhong, H.-J.; He, B.; Kwong, D. W.; Ma, D.-L.; Leung, C.-H. An iridium (III) complex inhibits JMJD2 activities and acts as a potential epigenetic modulator. J. Med. Chem. 2015, 58 (16), 6697-6703.

(7) Lu, L.; Wang, M.; Liu, L.-J.; Wong, C.-Y.; Leung, C.-H.; Ma, D.-L. A luminescence switch-on probe for terminal deoxynucleotidyl transferase (TdT) activity detection by using an iridium (III)-based i-motif probe. Chem. Comm. 2015, 51 (49), 9953-9956.

(8) Lin, S.; Lu, L.; Liu, J.-B.; Liu, C.; Kang, T.-S.; Yang, C.; Leung, C.-H.; Ma, D.-L. A G-quadruplex-selective luminescent iridium (III) complex and its application by long lifetime. Biochimica et Biophysica Acta (BBA)-General Subjects 2017, 1861 (5), 1448-1454.

(9) Blazer, L. L.; Roman, D. L.; Muxlow, M. R.; Neubig, R. R. Use of Flow Cytometric Methods to Quantify Protein - Protein Interactions. Curr Protoc Cytom. 2010, 51 (1), 13.11. 1-13.11. 15.

(10) Bol, G. M.; Vesuna, F.; Xie, M.; Zeng, J.; Aziz, K.; Gandhi, N.; Levine, A.; Irving, A.; Korz, D.; Tantravedi, S.; Van Voss, M. R. H.; Gabrielson, K.; Bordt, E. A.; Polster, B. M.; Cope, L.; van der Groep, P.; Kondaskar, A.; Rudek, M. A.; Hosmane, R. S.; van der Wall, E.; van Diest, P. J.; Tran, P. T.; Raman, V. Targeting DDX3 with a small molecule inhibitor for lung cancer therapy. EMBO Mol. Med. 2015, 7 (5), 648-669.

(11) Yang, C.; Wang, W.; Chen, L.; Liang, J.; Lin, S.; Lee, M. Y.; Ma, D. L.; Leung, C. H. Discovery of a VHL and HIF1alpha interaction inhibitor with in vivo angiogenic activity via structure-based virtual screening. Chem. Commun. 2016, 52 (87), 12837-12840, DOI: 10.1039/c6cc04938a.

(12) Yang, C.; Wang, W.; Li, G. D.; Zhong, H. J.; Dong, Z. Z.; Wong, C. Y.; Kwong, D. W.; Ma, D. L.; Leung, C. H. Anticancer osmium complex inhibitors of the HIF-1alpha and p300 protein-protein interaction. Sci Rep 2017, 7, 42860, DOI: 10.1038/srep42860.

(13) Lee, H.; Habas, R.; Abate-Shen, C. MSX1 cooperates with histone H1b for inhibition of transcription and myogenesis. Science 2004, 304 (5677), 1675-1678. 
(14) Li, P.-H.; Liu, L.-H.; Chang, C.-C.; Gao, R.; Leung, C.-H.; Ma, D.-L.; David Wang, H.-M. Silencing stem cell factor gene in fibroblasts to regulate paracrine factor productions and enhance c-kit expression in melanocytes on melanogenesis. Int. J. Mol. Sci. 2018,19 (5), 1475. (15) Sinha, S.; Malonia, S. K.; Mittal, S. P.; Singh, K.; Kadreppa, S.; Kamat, R.; Mukhopadhyaya, R.; Pal, J. K.; Chattopadhyay, S. Coordinated regulation of p53 apoptotic targets BAX and PUMA by SMAR1 through an identical MAR element. The EMBO journal 2010,29 (4), 830-842.

(16) Chen, H.; Yuan, Y.; Zhang, C.; Luo, A.; Ding, F.; Ma, J.; Yang, S.; Tian, Y.; Tong, T.; Zhan, Q. Involvement of S100A14 protein in cell invasion by affecting expression and function of matrix metalloproteinase (MMP)-2 via p53-dependent transcriptional regulation. J. Biol. Chem. 2012, $287(21), 17109-17119$

\section{Supplementary Tables}

Table S1. Primer sequences used in this paper.

\begin{tabular}{lll}
\hline Name & sense & antisense \\
\hline p21 $^{15}$ & 5'-CGCTCTACATCTTCTGCCTT -3' & 5'-GACAGCGCTGGGAAGGAGC -3' \\
\hline Bax $^{15}$ & 5'-TCAGCACAGATTAGTTTCTG -3' & 5'- GGGATTACAGGCATGAGCTA -3' \\
\hline MMP-2 $^{16}$ & 5'- TGACACGGAGACAGGAAGTG-3' $^{\prime}$ & 5'- GCATCTTGGTGAGGTGATGA-3' \\
\hline
\end{tabular}



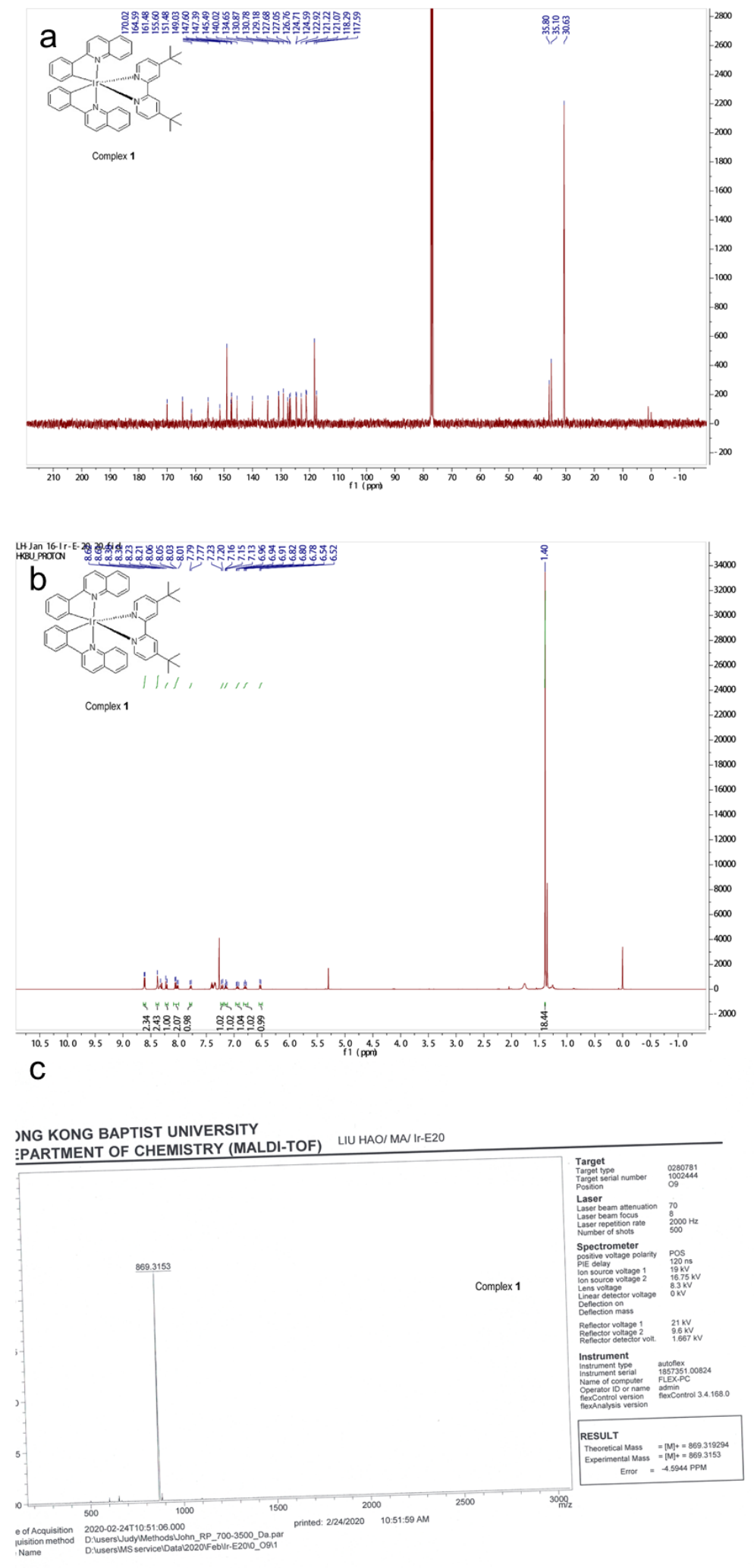

Figure S1. (a) ${ }^{1} \mathrm{C}$ NMR of complex 1, (b) ${ }^{1} \mathrm{H}$ NMR of complex 1, (c) HRMS of complex 1. 


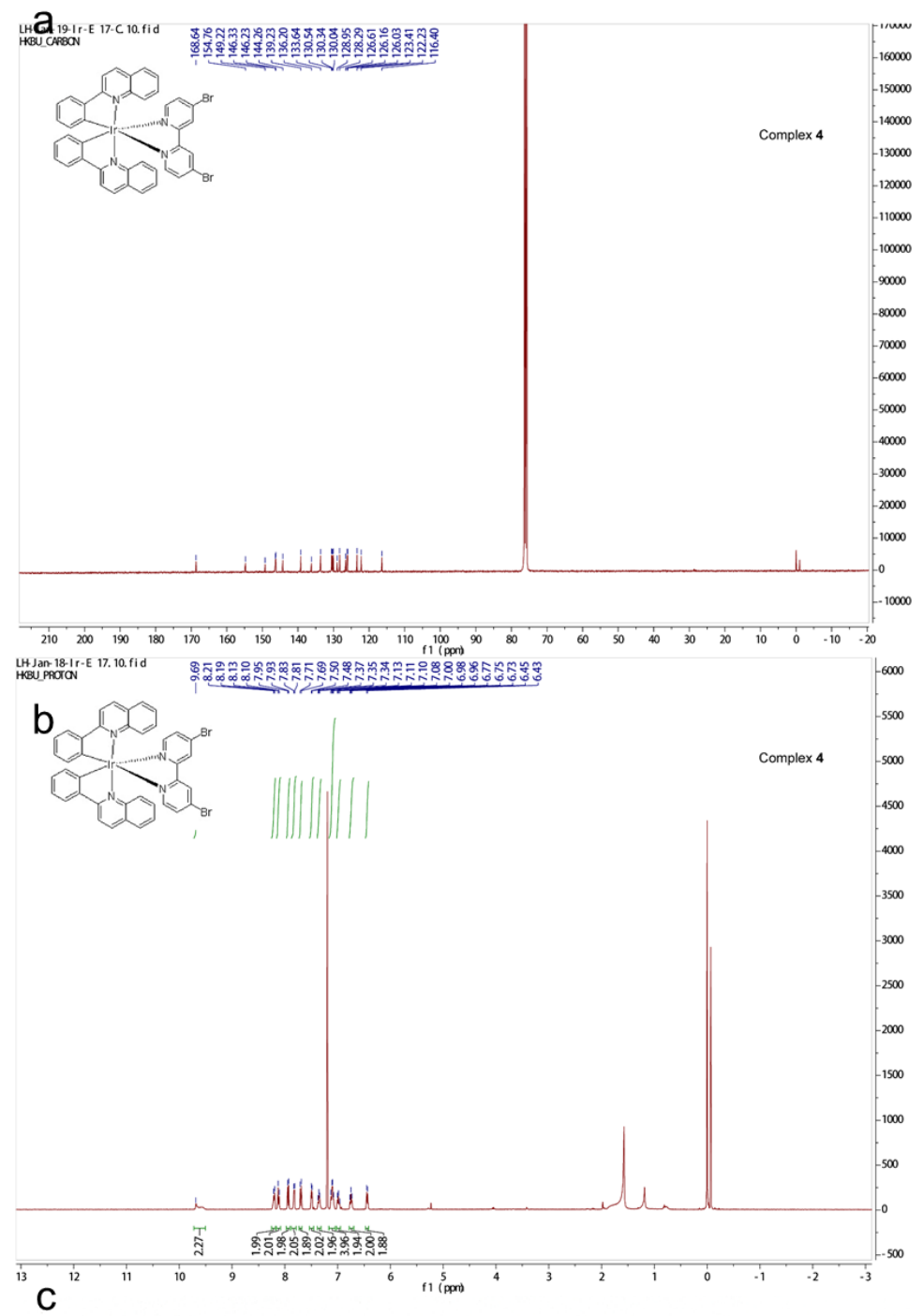

JNG KONG BAPTIST UNIVERSITY

EPARTMENT OF CHEMISTRY (MALDI-TOF) LIU HAO/ MA Ir-E17

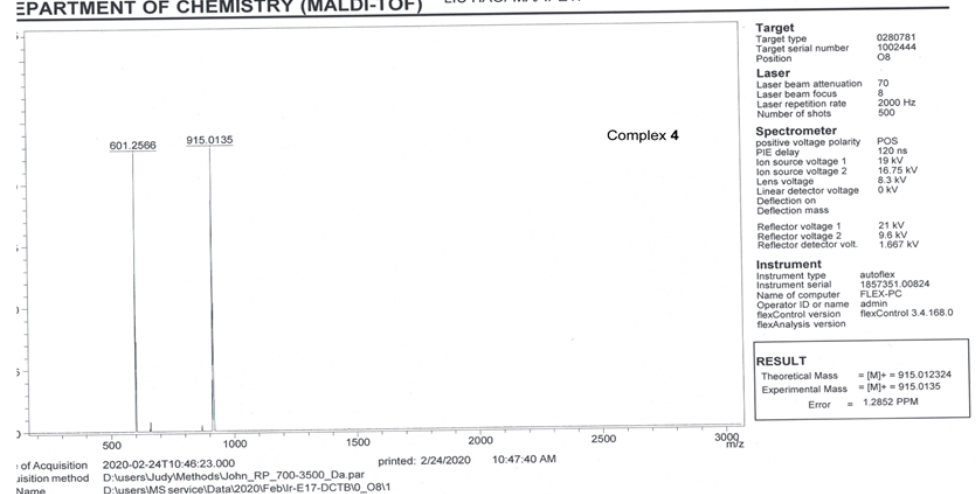

Figure S2. (a) ${ }^{1} \mathrm{C}$ NMR of complex 4, (b) ${ }^{1} \mathrm{H}$ NMR of complex 4, (c) HRMS of complex 4. 
a

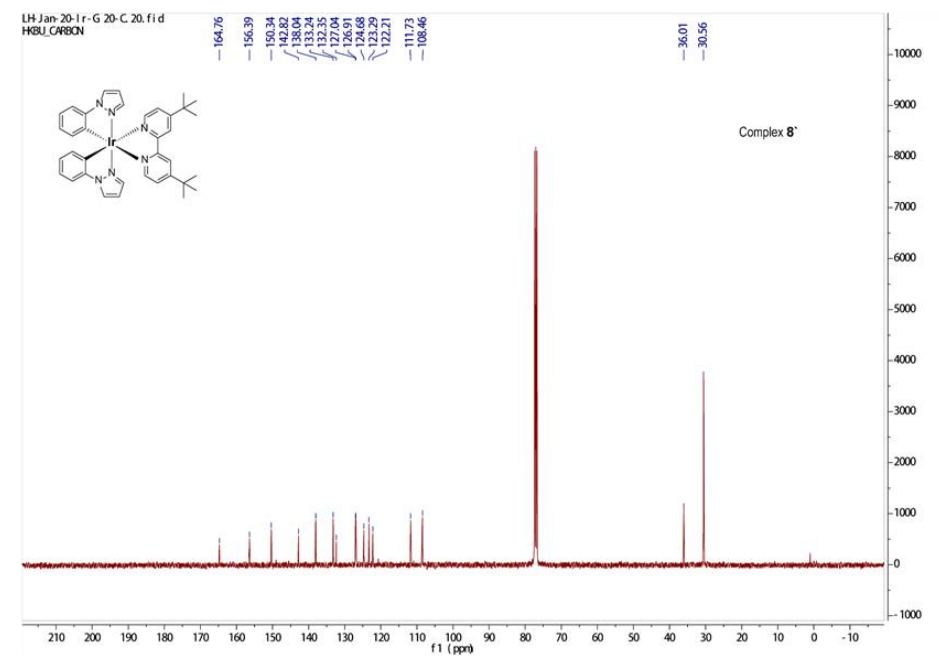

$\mathrm{b}$

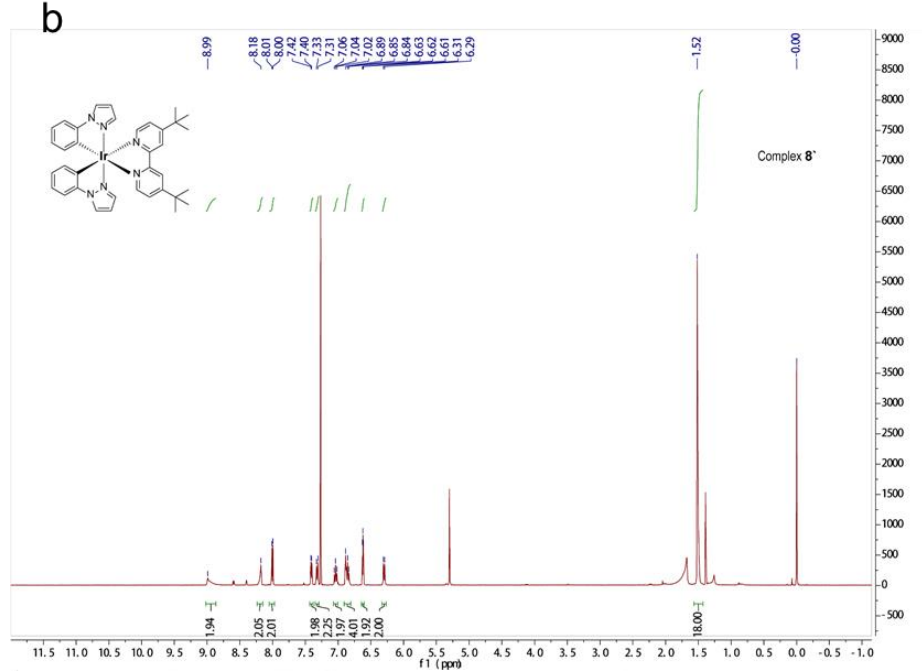

C

JNG KONG BAPTIST UNIVERSITY

EPARTMENT OF CHEMISTRY (MALDI-TOF) LIU HAO/ MA II-G-20

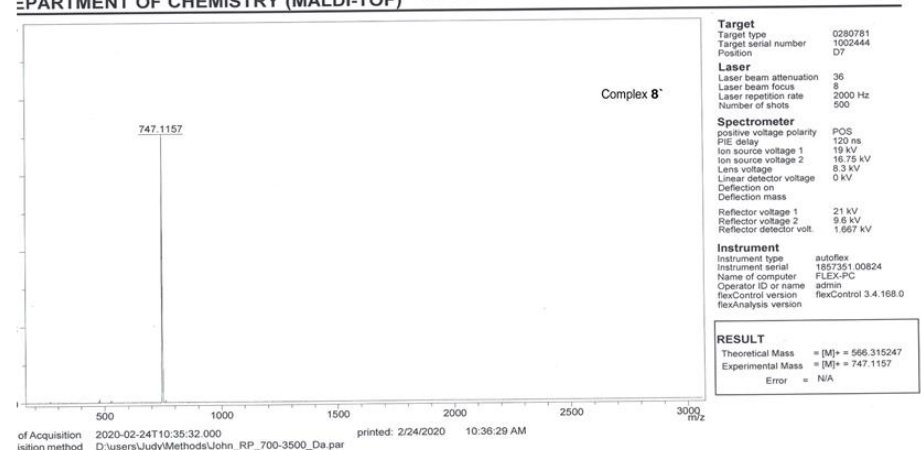

Figure S3. (a) ${ }^{1} \mathrm{C}$ NMR of complex 8, (b) ${ }^{1} \mathrm{H}$ NMR of complex 8 , (c) HRMS of complex 8 

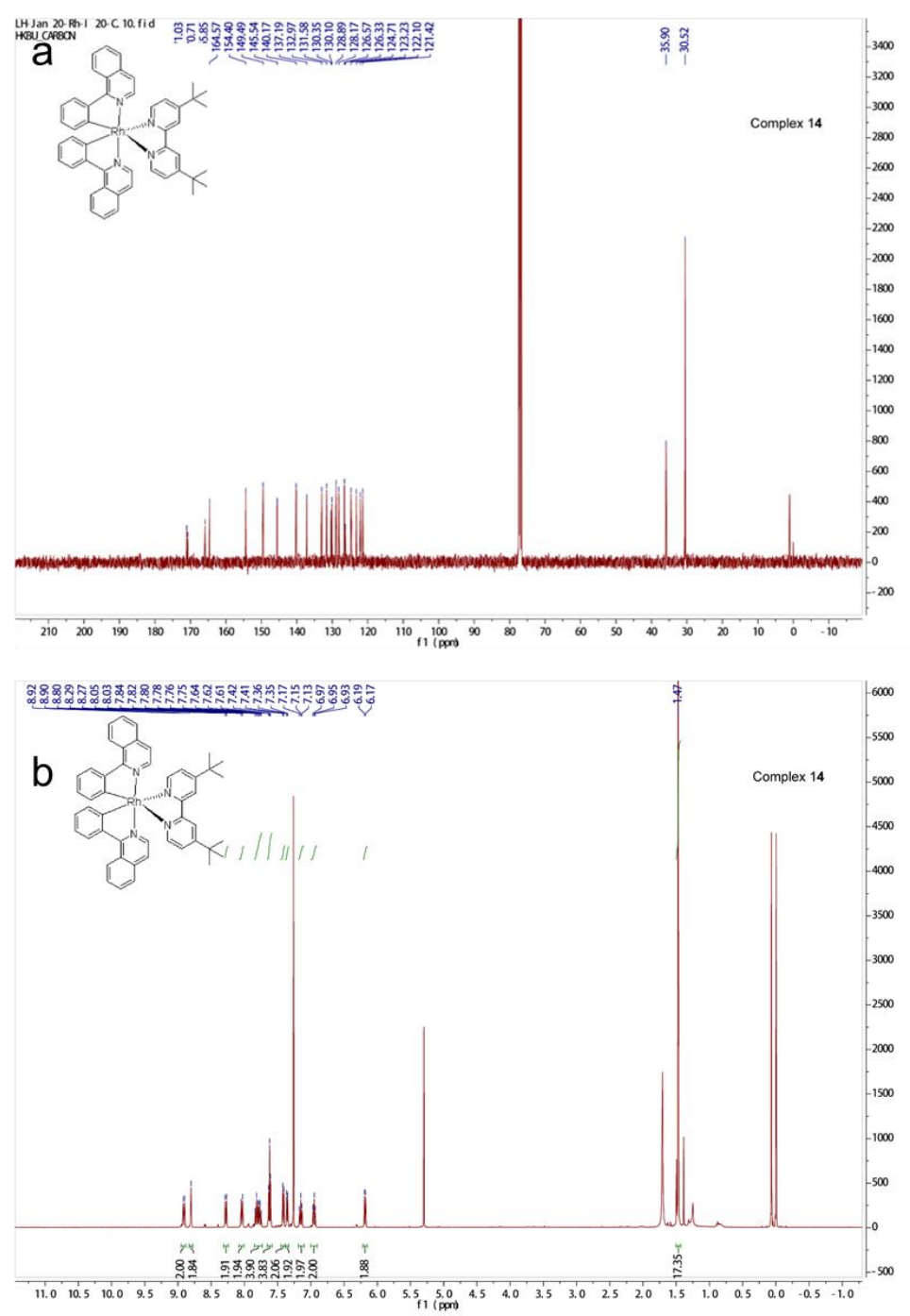

C

JNG KONG BAPTIST UNIVERSITY (MALDI-TOF) LIU HAO/ MA Rh-1-20

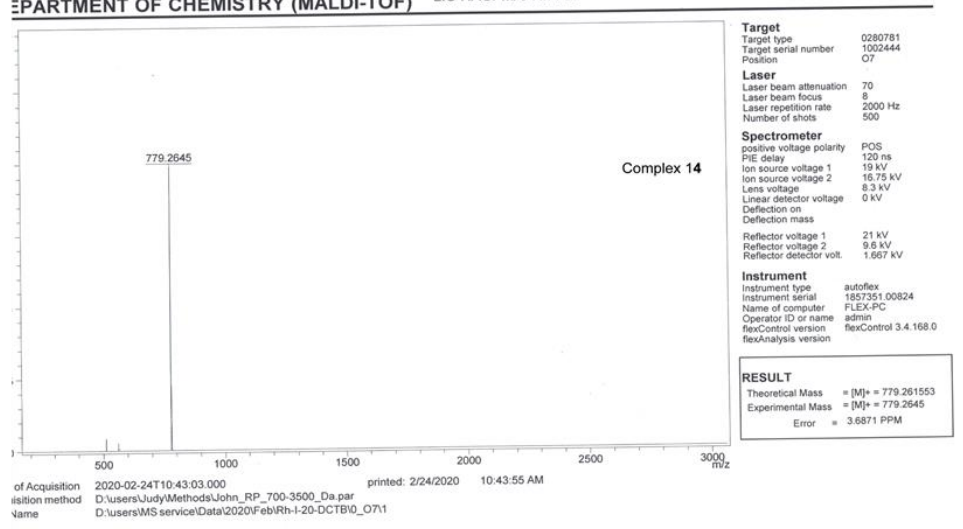

Figure S4. (a) ${ }^{1} \mathrm{C}$ NMR of complex 14, (b) ${ }^{1} \mathrm{H}$ NMR of complex 14, (c) HRMS of complex 14 
a

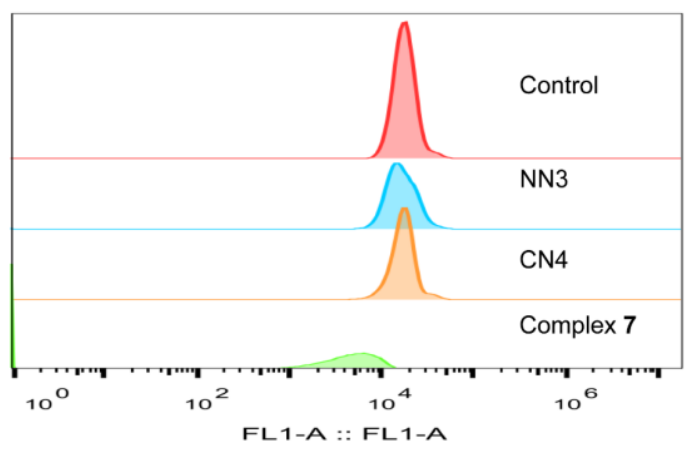

b

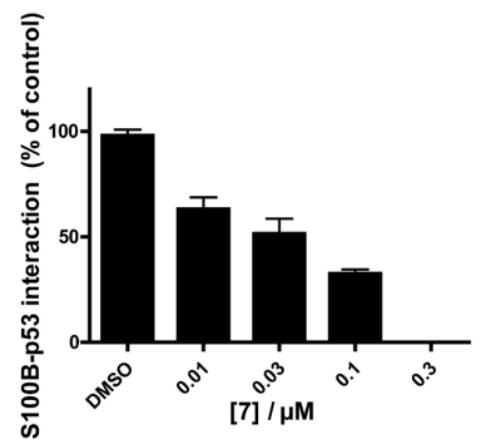

c

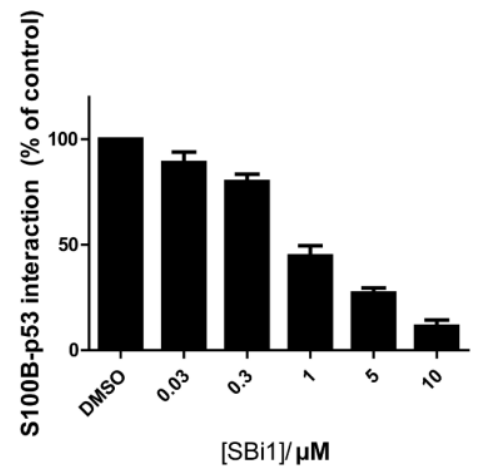

Figure S5. Complex 7 selectively inhibits the S100B/p53 PPI. (a) Effects of NN3 and CN4 ligands (10 $\mu \mathrm{M})$ on the inhibition of S100B/p53 PPI by FCPIA. (b, c) Effects of complex 7 and SBi1 on the S100B/p53 PPI by FCPIA. Error bars represent standard deviation of the means of the results from three independent experiments. 
a

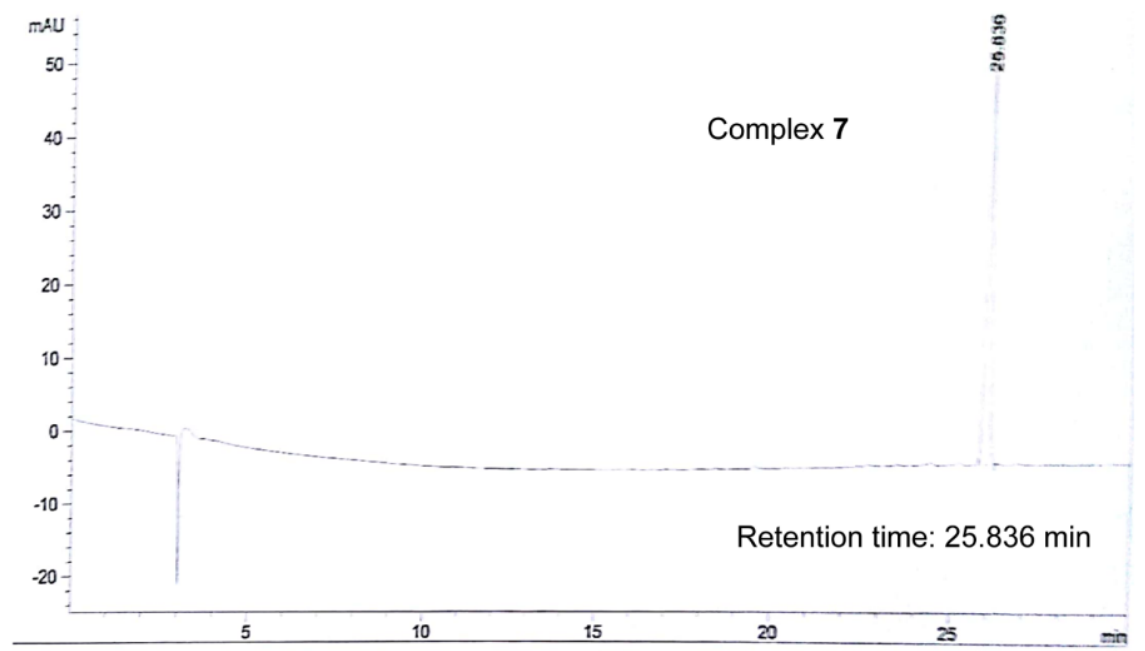

b

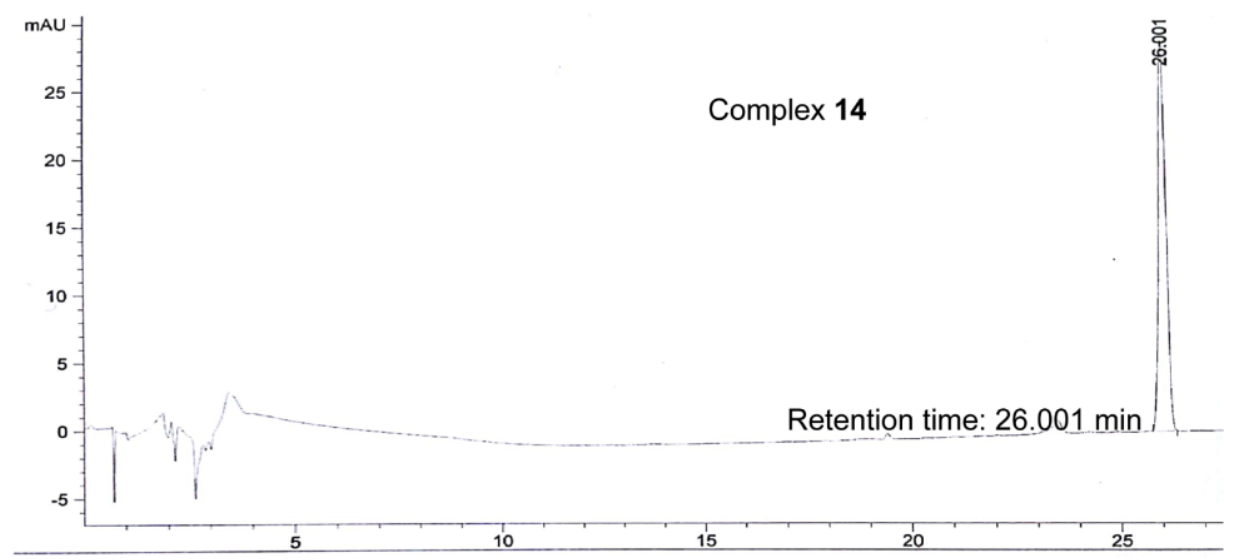

C

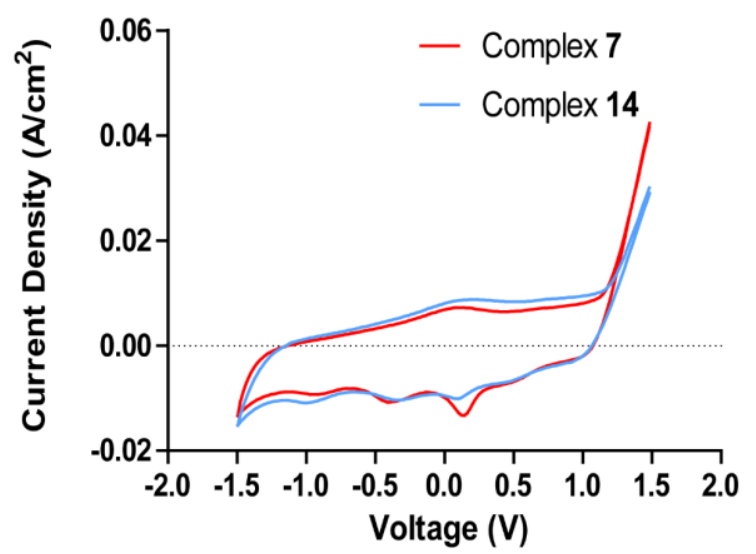

Figure S6. Retention times and HPLC spectra for complexes 7 and 14 were detected by reverse phase HPLC. Retention time: (a) complex 7: $25.836 \mathrm{~min}$, and (b) complex 14: $26.001 \mathrm{~min}$. (c) Cyclic voltammetry of complexes 7 and 14. Data were obtained at a scan rate of $20 \mathrm{~V} \mathrm{~s}^{-1}$ in Tris-buffer with a platinum wire counter electrode and an $\mathrm{Ag} / \mathrm{AgCl}$ as reference electrode. 
a

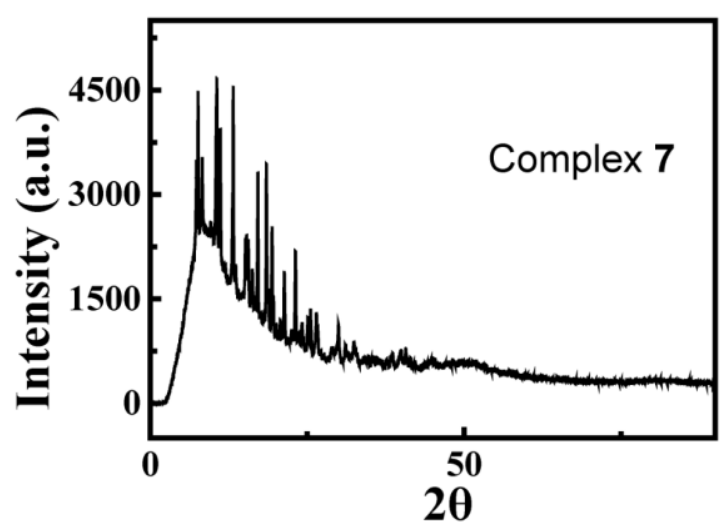

b

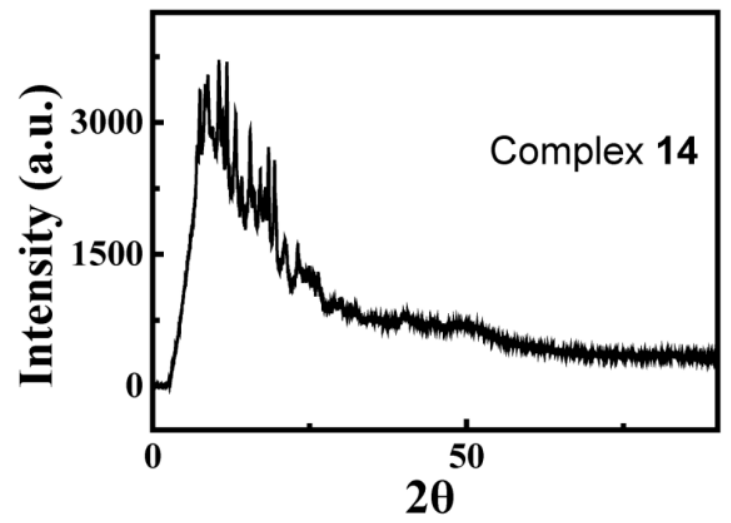

Figure S7. (a, b) X-ray powder diffraction patterns of complexes 7 and 14.

a

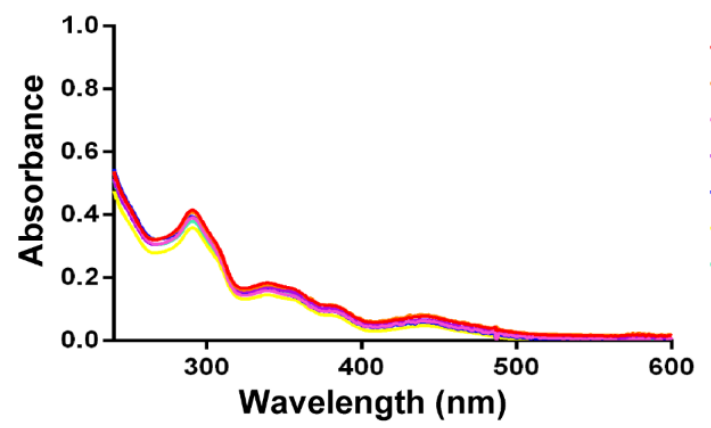

b

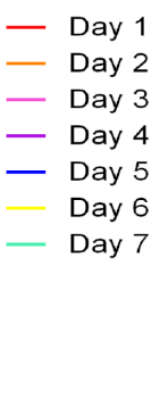

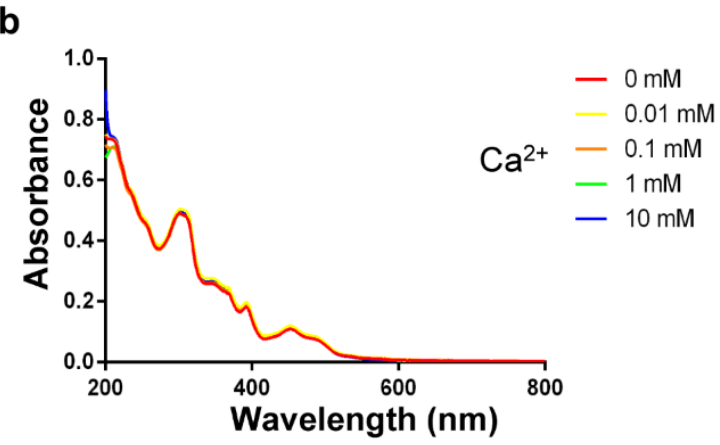

C

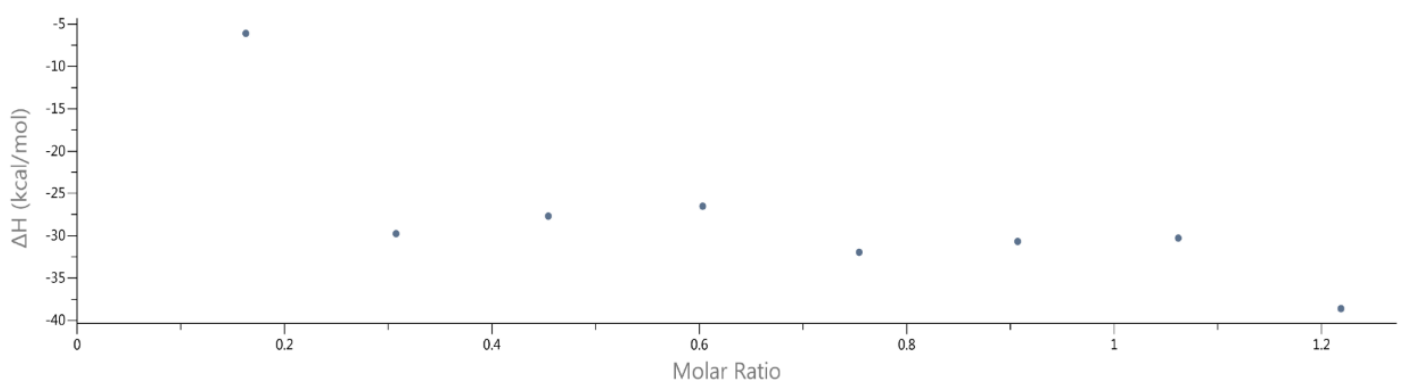

d

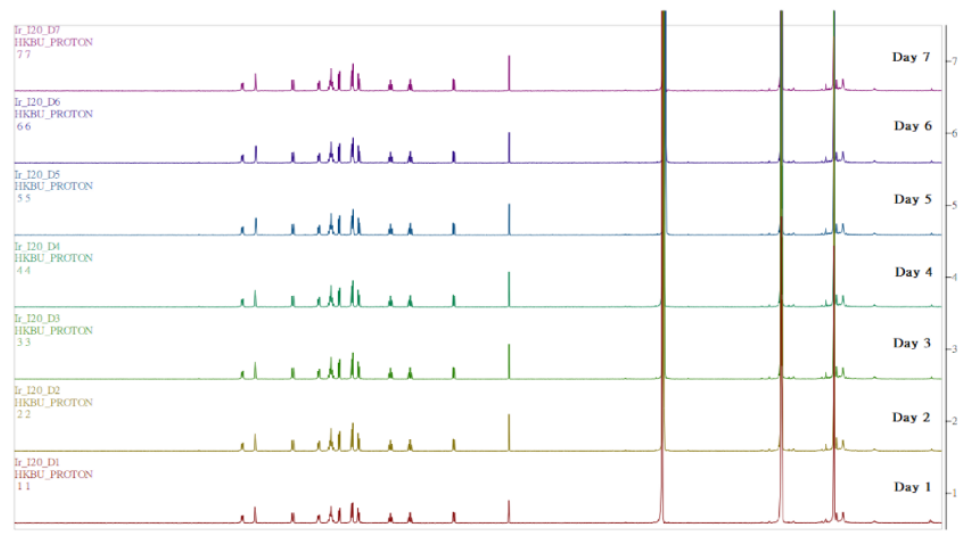

Figure S8. Stability of complex 7. (a) UV-Vis absorption of complex 7 at $5 \mu \mathrm{M}$ in $80 \%$ acetonitrile/20\% $20 \mathrm{mM}$ Tris- $\mathrm{HCl}$ buffer $\left(\mathrm{pH}=7.4\right.$ ) at $25^{\circ} \mathrm{C}$ over 7 days. (b) UV/Vis absorption of the compound 7 at $5 \mu \mathrm{M}$ in $20 \mathrm{mM}$ Tris- $\mathrm{HCl}$ buffer $(\mathrm{pH}=7.4)$ at $25^{\circ} \mathrm{C}$ in the absence or presence of $\mathrm{Ca}^{2+}$. (c) Representative ITC data of $\mathrm{Ca}^{2+}$ titrated into complex 7. (d) ${ }^{1} \mathrm{H}$ NMR spectra of complex 7 at $5 \mathrm{mM}$ in $90 \%\left[d_{6}\right] \mathrm{DMSO} / 10 \% \mathrm{D}_{2} \mathrm{O}$ at $25^{\circ} \mathrm{C}$ over 7 days. 


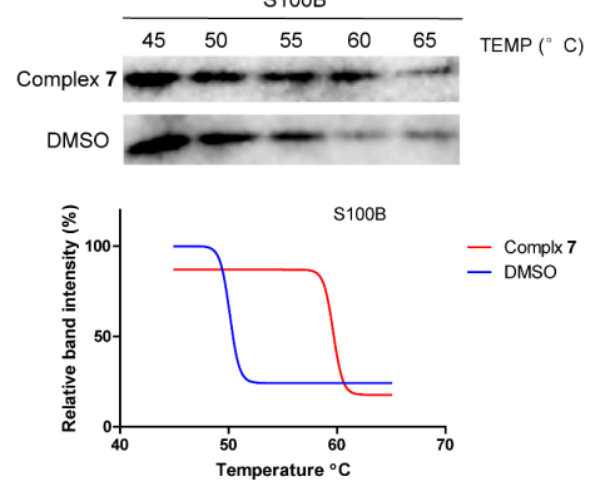

c
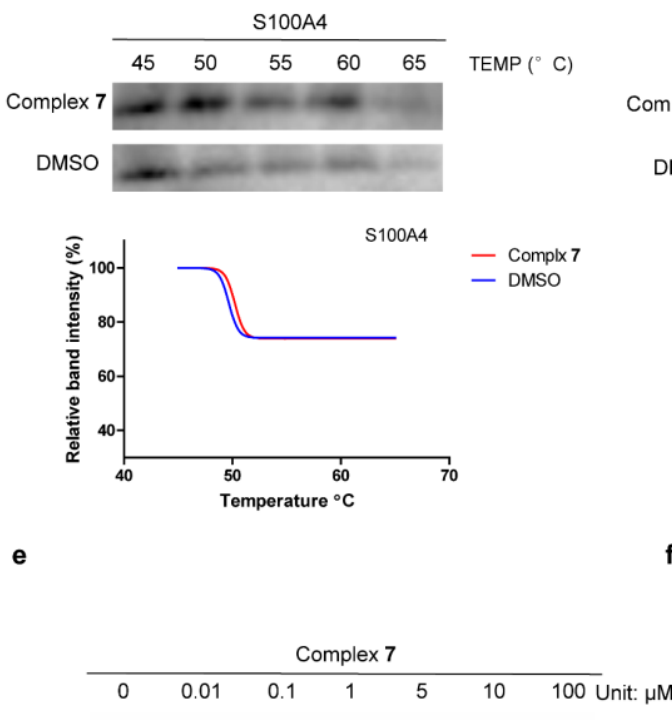

$\mathrm{S} 100 \mathrm{~B}$

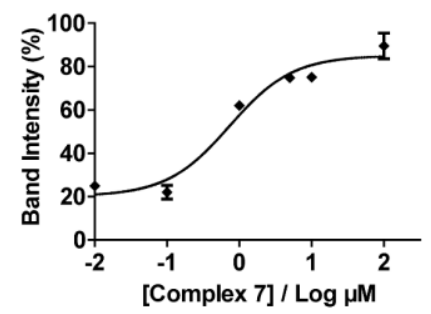

h

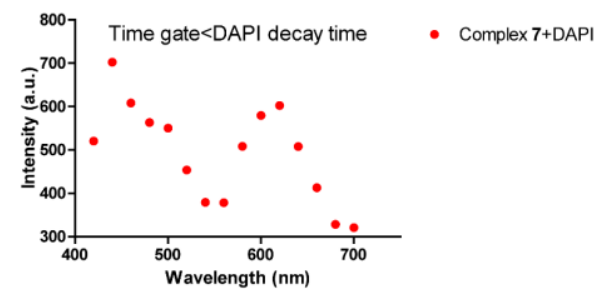

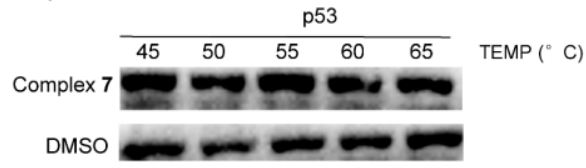

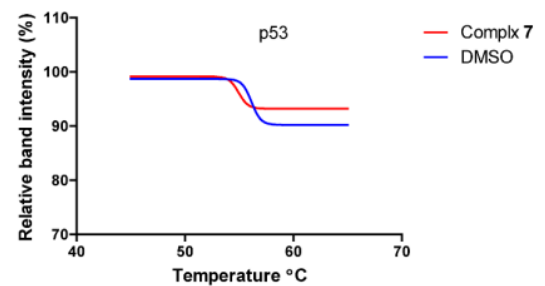

d
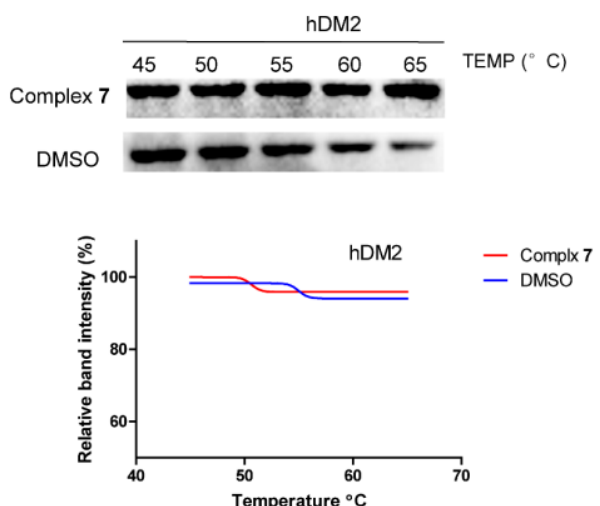

$\mathbf{f}$

- S100B

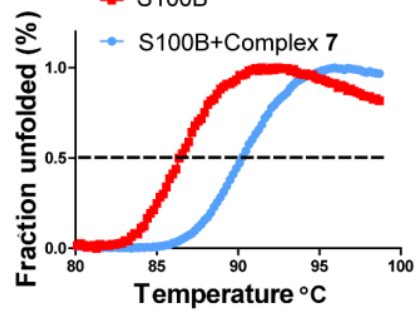

g
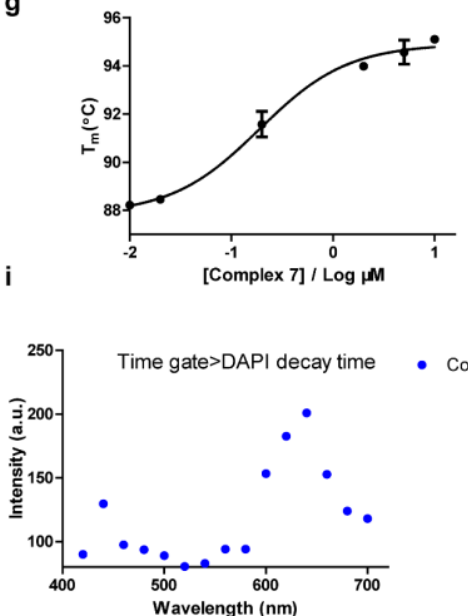

Figure S9. Complex 7 engages S100B protein in cell lysates and in vitro. (a)The effects of complex 7 on the thermal stability of S100B. (b) The effects of complex 7 on the thermal stability of p53. (c)The effects of complex 7 on the thermal stability of

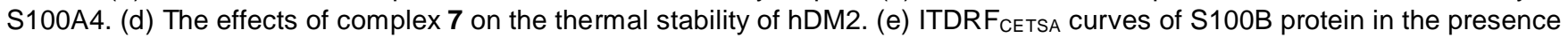
of complex $7(0-100 \mu \mathrm{M})$. The protein samples were detected by Western blotting and the band density were analyzed. (f) Melt profile of S100B protein with or without complex $7(1 \mu \mathrm{M})$ by protein thermal shift assay. $(\mathrm{g})$ The dependence of the melting temperature of S100B protein on the concentration of complex $7(0-10 \mu \mathrm{M})$ by protein thermal shift assay. (h) Time-resolved spectra of complex $7(1 \mu \mathrm{M})$ and the nuclear dye DAPI $(1 \mu \mathrm{M})$ in A375 cells with time gate set to less than the DAPI decay time. (i) Time-resolved spectra of complex $7(1 \mu \mathrm{M})$ and the nuclear dye DAPI $(1 \mu \mathrm{M})$ in A375 cells with time gate set to greater than the DAPI decay time. 
a
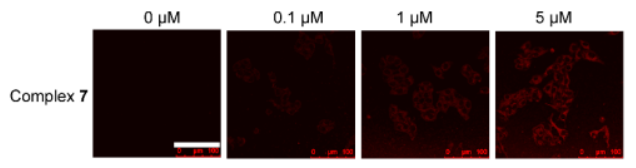

C
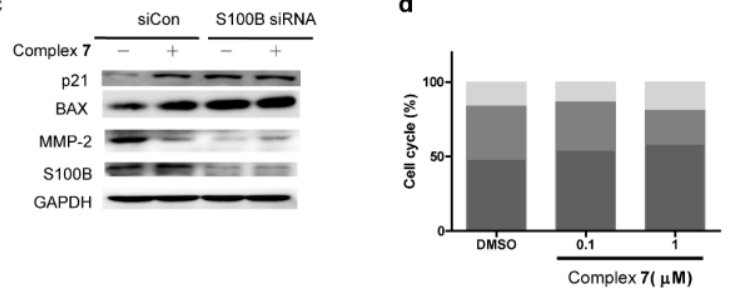

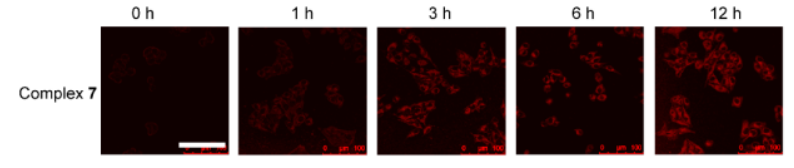

e
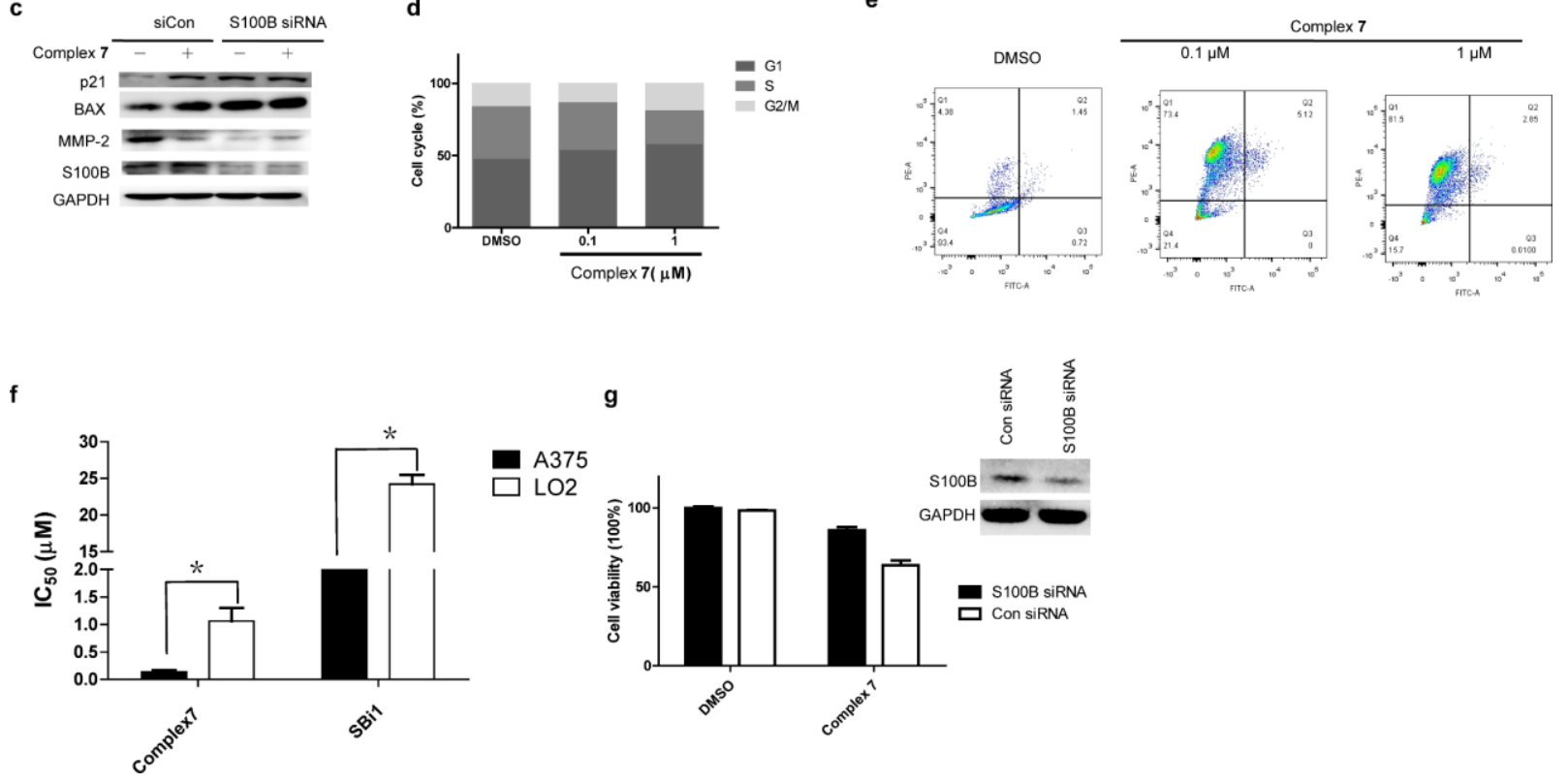

Figure S10. (a) Confocal imaging of $A 375$ cells incubated with complex $7(0-5 \mu \mathrm{M})$ for $1 \mathrm{~h}$ at $37^{\circ} \mathrm{C}$. (b). Confocal imaging of A375 cells incubated with complex $7(1 \mu \mathrm{M})$ for $0-12 \mathrm{~h}$ at $37^{\circ} \mathrm{C}$. (c) The effect of complex 7 on MMP-2, p21 and Bax protein expression after S100B knockdown by S100B siRNA in A375 cells. (d) The effect of complex 7 on the cell cycle in A375 cells. (e) The effect of complex 7 on apoptosis in A375 cells. (f) The effect of complex 7 on cell viability in LO2 and A375 cells. (g) The effect of complex 7 on A375 cell viability after knockdown S100B by S100B siRNA. Error bars represent the standard deviations of the results from three independent experiments. ${ }^{*} p<0.05$ compared with control group. 
a

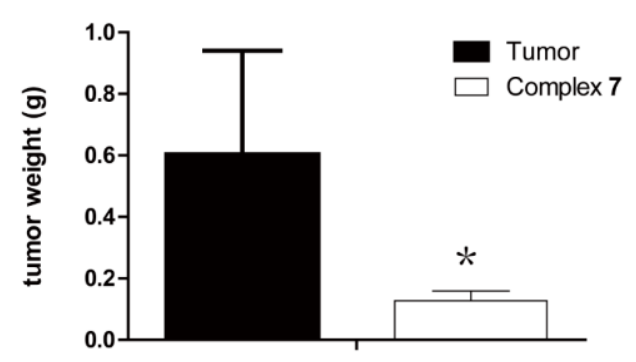

C

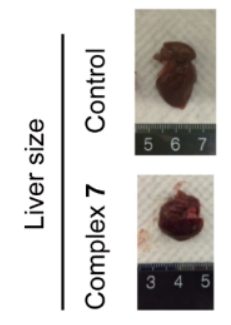

f

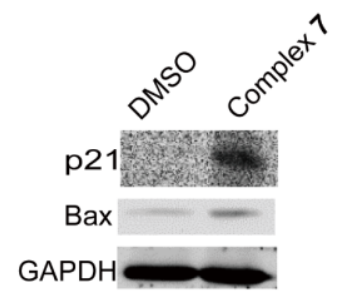

b

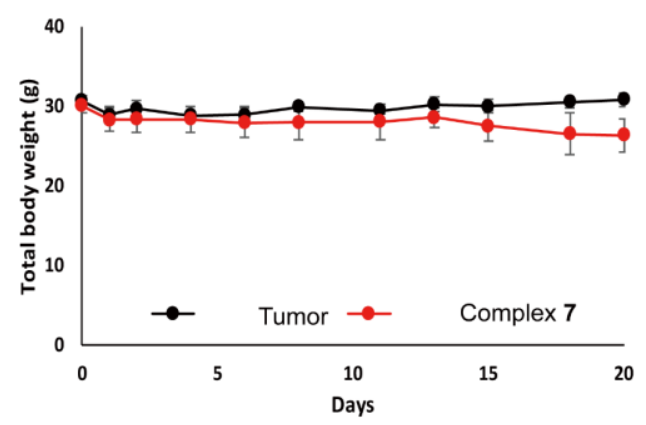

e

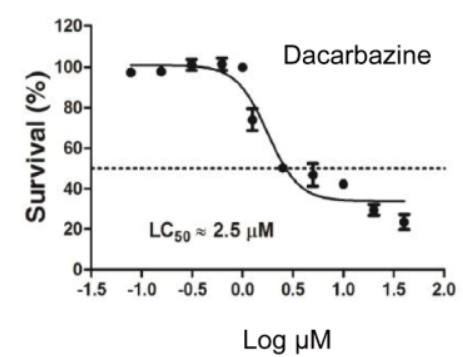

g

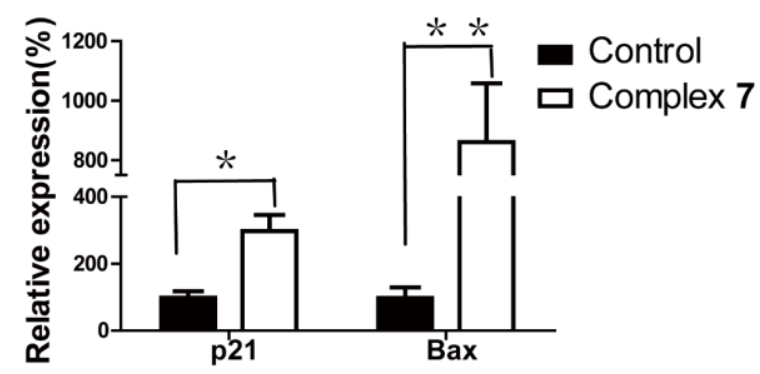

Figure S11. Effects of complex 7 on A375 and B16F10 xenografts model. (a) Effects of complex 7 on tumor weight in A375 xenografts model. (b) Effects of complex 7 on mice body weight in A375 xenografts model. (c) Representative images of dissected liver tissue from each group in A375 xenografts model. (d, e) After $48 \mathrm{~h}$ of continuous administration, the LC ${ }_{50}$ of complex 7 and Dacarbazine were detected in A375 xenografts model. (f) Effect of complex 7 on p21 and Bax protein levels in A375 xenograft model.(g) Effect of complex 7 on p21 and Bax RNA levels in A375 xenograft model. Error bars represent the standard deviations of the results from three independent experiments. ${ }^{*} p<0.05,{ }^{* *} p<0.01$ compared with control group. 